\title{
The endoscope-assisted supraorbital "keyhole" approach for anterior skull base meningiomas: an updated meta-analysis
}

\author{
Danyal Z. Khan ${ }^{1}$ (D) - Ivo S. Muskens ${ }^{2} \cdot$ Rania A. Mekary ${ }^{3,4}$ - Amir H. Zamanipoor Najafabadi ${ }^{5}$ - Adel E. Helmy ${ }^{1}$. \\ Robert Reisch ${ }^{6}$ - Marike L. D. Broekman ${ }^{2,3,7}$ - Hani J. Marcus ${ }^{8,9}$
}

Received: 3 June 2020 / Accepted: 16 August 2020 / Published online: 5 September 2020

(C) The Author(s) 2020

\begin{abstract}
Introduction The gold-standard treatment for symptomatic anterior skull base meningiomas is surgical resection. The endoscope-assisted supraorbital "keyhole" approach (eSKA) is a promising technique for surgical resection of olfactory groove (OGM) and tuberculum sellae meningioma (TSM) but has yet to be compared with the microscopic transcranial (mTCA) and the expanded endoscopic endonasal approach (EEA) in the context of existing literature.

Methods An updated study-level meta-analysis on surgical outcomes and complications of OGM and TSM operated with the eSKA, mTCA, and EEA was conducted using random-effect models.

Results A total of 2285 articles were screened, yielding 96 studies (2191 TSM and 1510 OGM patients). In terms of effectiveness, gross total resection incidence was highest in mTCA (89.6\% TSM, 91.1\% OGM), followed by eSKA (85.2\% TSM, $84.9 \%$ OGM) and EEA (83.9\% TSM, 82.8\% OGM). Additionally, the EEA group had the highest incidence of visual improvement (81.9\% TSM, 54.6\% OGM), followed by eSKA (65.9\% TSM, 52.9\% OGM) and mTCA (63.9\% TSM, 45.7\% OGM). However, in terms of safety, the EEA possessed the highest cerebrospinal fluid leak incidence (9.2\% TSM, 14.5\% OGM), compared with eSKA (2.1\% TSM, 1.6\% OGM) and mTCA (1.6\% TSM, 6.5\% OGM). Finally, mortality and intraoperative arterial injury were $1 \%$ or lower across all subgroups.

Conclusions In the context of diverse study populations, the eSKA appeared not to be associated with increased adverse outcomes when compared with mTCA and EEA and offered comparable effectiveness. Case-selection is paramount in establishing a role for the eSKA in anterior skull base tumours.
\end{abstract}

Keywords Endoscopic transsphenoidal surgery $\cdot$ Microscopic transcranial surgery $\cdot$ Supraorbital keyhole $\cdot$ Skull base surgery · Tuberculum Sellae Meningioma · Olfactory groove meningioma

This article is part of the Topical Collection on Tumor - Meningioma

Electronic supplementary material The online version of this article (https://doi.org/10.1007/s00701-020-04544-x) contains supplementary material, which is available to authorized users.

Danyal Z. Khan

danyal.khan@nhs.net

1 Division of Neurosurgery, Department of Clinical Neurosciences, University of Cambridge, Cambridge, UK

2 Department of Neurosurgery, Haaglanden Medical Center and Leiden University Medical Center, The Hague, The Netherlands

3 Computational Neurosciences Outcomes Center, Department of Neurosurgery, Brigham and Women's Hospital, Boston, MA, USA

4 Department of Pharmaceutical Business and Administrative Sciences, School of Pharmacy, MCPHS University, Boston, MA, USA
5 Department of Neurosurgery, University Neurosurgical Centre Holland, Leiden University Medical Centre, Haaglanden Medical Centre and Haga Teaching Hospital, Leidenand The Hague, The Netherlands

6 ENDOMIN - Center for Endoscopic and Minimally Invasive Neurosurgery, Hirslanden Hospital, Zurich, Switzerland

7 Department of Neurology, Massachusetts General Hospital, Harvard Medical School, Boston, MA, USA

8 Department of Neurosurgery, National Hospital for Neurology and Neurosurgery, London, UK

9 Wellcome/EPSRC Centre for Interventional and Surgical Sciences, University College London, London, UK 


$\begin{array}{ll}\text { Abbreviations } \\ \text { TSM } & \text { Tuberculum sellae meningioma } \\ \text { OGM } & \text { Olfactory groove meningioma } \\ \text { eSKA } & \begin{array}{l}\text { Endoscope-assisted supraorbital "keyhole" } \\ \text { approach }\end{array} \\ \text { EEA } & \text { Expanded endoscopic endonasal approach } \\ \text { mTCA } & \text { Microscopic transcranial approach } \\ \text { GTR } & \text { Gross total resection } \\ \text { CSF } & \text { Cerebrospinal fluid } \\ \text { WHO } & \text { World Health Organization } \\ \text { mNOS } & \text { Modified New-Castle Ottawa Scale } \\ \text { ICA } & \text { Internal carotid arteries } \\ \text { ACP } & \text { Anterior clinoid processes } \\ \text { LP } & \text { Lamina papyracea } \\ \text { CI } & \text { Confidence Interval }\end{array}$

\section{Introduction}

The gold standard treatment for symptomatic anterior skull base meningiomas is complete surgical resection-if possible to do so without causing significant morbidity. Although the traditional microscopic transcranial approach (mTCA) has proven to be effective at removing such tumours $[84,86]$, minimally invasive surgical approaches may offer the possibility of reducing brain exposure and manipulation, and therefore increasing safety [105]. However, these less invasive techniques are often technically challenging with steep learning curves [105]. Factors influencing case-by-case surgical decision-making include the preservation of olfaction and vision, tumour size and location, the involvement of neurovascular structures, surgical experience, and patient choice $[24,86]$.

A previous comprehensive meta-analysis comparing the traditional mTCA and the expanded endoscopic endonasal approach (EEA) found similar gross total resection (GTR) and mortality rates, with more favourable visual outcomes but higher cerebrospinal (CSF) leak incidence with EEA [84]. This generally corroborates with findings from other systematic reviews in the field $[24,59,110]$. However, a third approach - the endoscope-assisted supraorbital "keyhole" approach (eSKA) - has yet to be compared with mTCA and EEA in the context of existing literature. This approach includes multiple variations (such as the medial supraorbital, basal supraorbital, and lateral supraorbital approaches) that are unified by the principle of achieving surgical control of a deep-seated lesion whilst minimizing iatrogenic injury to the brain (via exposure, retraction, and manipulation) [102, 107]. This is achieved through using smaller craniotomies with smaller dural openings and may theoretically reduce postoperative complications and length of stay, whilst improving cosmesis, patient satisfaction and carrying lower CSF leak rates than the EEA $[102,104,105,107]$. However, important limitations of the eSKA include (a) difficult visualization and orientation of deep structures, (b) difficult (almost co-axial) instrument control owing to instrument size and the fulcrum effect (requiring specialized instruments), and (c) limited and predefined surgical corridors which require extensive preoperative planning $[102,107]$. Endoscope assistance provides a high light intensity with wider viewing angles distal to the craniotomy, allowing high-resolution visualization of deeper tissues. Indeed, combined with image-guidance systems and intra-operative adjuncts (e.g. ultrasound, MRI), endoscopes facilitate surgical orientation and resection during keyhole approaches $[102,107]$.

Therefore, we updated a previous systematic review and meta-analysis comparing mTCA with EEA and extended this review with the eSKA for the management of olfactory groove (OGM) and tuberculum sellae meningiomas (TSM).

\section{Methods}

In order to identify studies reporting on outcomes of surgically treated TSMs and OGMs, we adapted our previous methodology [84], expanding our search to include eSKA and updating our search to include mTCA and EEA articles published after our last search.

\section{Search strategy}

This review was conducted in accordance with the Preferred Reporting Items for Systematic Reviews and Meta-Analyses (PRISMA) Statement [81]. A search strategy was created using the keywords "Meningioma," "Tuberculum Sellae," "Olfactory Groove," and synonyms (Appendix A). Studies were included if they reported on (1) patients with olfactory groove (OGM) or tuberculum sellae (TSM) meningiomas; (2) patients undergoing surgery using the mTCA, EEA or eSKA approaches; and (3) surgical outcomes and complications. Exclusion criteria included case reports, commentaries, congress abstracts, reviews, animal studies, studies describing a combined surgical approach (for example EEA + mTCA), studies in paediatric patients $(<18$ years old), re-operations, and cadaveric studies. A date filter was applied, with articles from 2004 to 2020 being included - reflecting a period of the contemporary adaptation of endoscopic and keyhole approaches and the continuous improvement of traditional microsurgical approaches for the relevant pathologies $[11,15,32,106]$.

Both PubMed and Embase databases were searched on 19 April 2020. Duplicates were removed using Endnote X9. Independent title and abstract screening of updated results was performed in duplicate by two authors (DZK, HJM). Review of full-text articles ensued according to the inclusion/exclusion criteria. Any discrepancies in selection were settled out by discussion and mutual agreement. 


\section{Data extraction}

Data points extracted from the included articles comprised of patient characteristics (age, sex distribution), tumour characteristics (surgical approach used, sum of sample, tumour grade, tumour diameter or volume, follow-up length), outcomes (GTR, visual improvement), and complications (CSF leak, 30-day mortality, intra-operative arterial injury). World Health Organization (WHO) grading included recording the proportion of WHO Grade 1 tumours [72]. Of note, the grading system was revised in 2016 to include brain invasion as a criterion to upgrade Grade 1 tumours to Grade 2 [72]. Therefore, if any studies pre-2016 reported brain invasion amongst Grade 1 tumours, the respective tumours were upgraded accordingly [72]. Gross total resection (GTR) referred to Simpson Grades 1 and 2 as per our original methodology [84, 116]. Visual improvement was in the context of those with preoperative visual problems only. Mortality (within 30 days after resection) was recorded on an all-cause basis.

Owing to the not uncommon reporting of follow-up time as a median number of months (as opposed to mean), the estimated mean number of months was calculated as per recommendations of Hozo et al. [53]. Of note, in sample sizes greater than 25 , the sample's median follow-up is presented as the best estimate of the mean [53].

Importantly, studies that did not report specific outcomes for OGM/TSM and approach combination were excluded from the final meta-analysis. These studies were considered for qualitative analysis if the relevant the tumour (TSM or OGM) and approach (mTCA, EEA, or eSKA) combination of interest was $>50 \%$ of the study population $[9,48,98,105$, 111]. Similarly, articles that grouped TSM cases with planum sphenoidale meningiomas $[3,92]$ were considered for qualitative review only (owing to the similarity of these tumour groups) but not included in the final meta-analysis.

\section{Risk of bias assessment}

Study quality was assessed with a modified New-Castle Ottawa Scale (mNOS), which assesses two domains: sample selection and outcome reporting. The modification made to the original NOS was the exclusion of the "comparability" domain as this is not applicable to case series [126]. The scale is scored out of 6 ( 3 for selection domain, 3 for outcome domain). Publication bias was assessed using Begg's tests [8] and by generating funnel plots with and without trimand-fill method [34].

\section{Meta-analysis}

A meta-analysis was conducted using R 3.6.1 (The R Foundation, Austria) applying the "meta" package. Pooled incidence (using the random-effect model method of
DerSimonian and Laird [33]) was calculated for each approach (eSKA, mTCA, EEA), tumour (TSM, OGM), and outcome (GTR, arterial injury, visual improvement, CSF leakage, and mortality) combination. Study heterogeneity was assessed by calculating $I$-squared values [52] $\left(I^{2}>50 \%\right.$ considered significant) and Cochran's $Q$ test $(p<0.10)[36,52]$. Sensitivity analysis was performed by running the above analyses on a low risk of bias sub-group (mNOS score greater than or equal to 4).

Additionally, a univariate meta-regression was performed to explore the effect of mean age (continuous variable) and male percentage (continuous variable) on each approach, tumour, and outcome combination. Meta-regression was only performed if 8 or more studies were available for the outcome/ approach/tumour combination being explored. This threshold was chosen (a deviation from the standard threshold of 10) on a pragmatic basis, to reflect the relative paucity of literature from the newer eSKA approach [51]. This threshold was also applied to the performance of Begg's test, trim-and-fill analysis, and the generation of funnel plots.

\section{Results}

\section{Search results}

In all, after removing duplicates, 2285 articles were identified (Fig. 1). After screening for titles and abstracts, 2044 articles were excluded and 241 full texts were reviewed to yield 96 included studies. Fifty-three TSM-only case series were included in the meta-analysis of which 21 involved the EEA $[3,12,13,17,19,22,37,41,49,60,61,63,67,74,91,92$, $120,125,131], 37$ the mTCA $[1,3,6,13,20,21,26,29,38$, $43,45,55,60,63,64,66,68,74-76,78,79,82,85,88,92,95$, $97,98,108,112,114,120,124,127,130]$, and 5 the eSKA $[16,35,41,67,78]$ with 10 of these papers covering multiple approaches $[3,14,41,60,63,67,74,78,92,120]$. Twentyeight OGM-only case series were included in the metaanalysis of which 5 involved EEA [4, 28, 62, 70, 92], 24 in mTCA $[5,7,10,23,25,27,28,40,42,44,47,56,57,70,83$, $87,89,96,99,101,109,117,121,123], 3$ in eSKA [4, 39, 92], and with 4 of these studies detailing multiple approaches [4, 28, 70, 92]. Additionally, 15 studies explored both OGM and TSM $[9,30,31,50,54,58,65,93,94,103,105,113,122$, 128, 129]. Resultantly, the TSM group totalled 2191 patients and OSM group totalled 1519 patients (Tables 1 and 2).

\section{General characteristics}

The median number of patients per study was 20 (range: 395) for TSM and 19.5 (range: 2-129) for OGM. The average percentage of male patients was $24 \%$ for TSM and $31 \%$ for OGM. The median mean of age was 54.2 years for TSM and 
Fig. 1 PRISMA flowchart detailing search strategy and systematic article selection

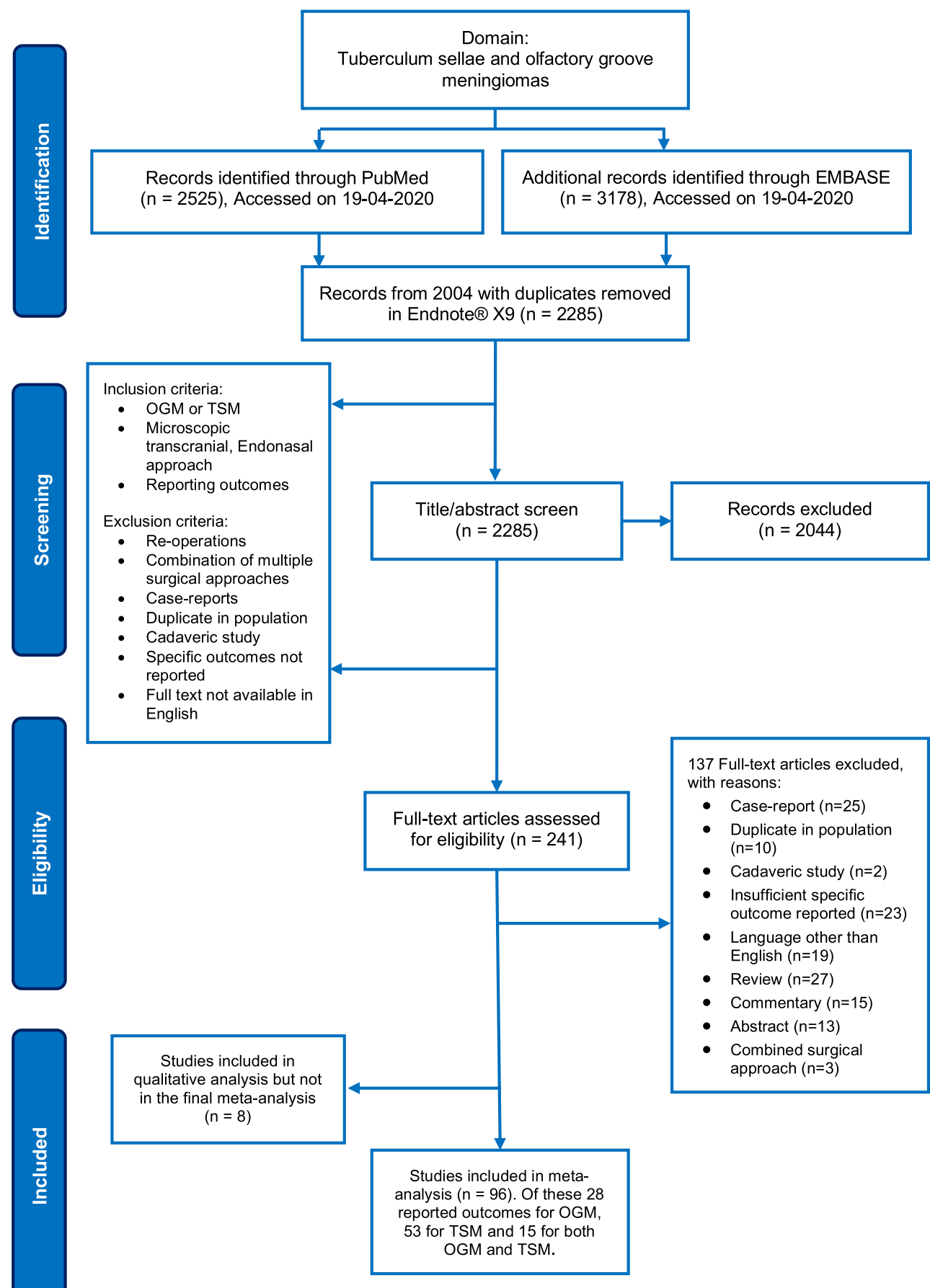

54.75 years for OGM. The median mean of follow-up time for TSM was 32 months (reported in 55/67 studies) for and 44.5 months for OGM studies (reported in 39/43 studies). The modified NOS score varied between 2/6 and 6/6 amongst the TSM and OGM case series, with predominant factors affecting this variance being a description of follow-up and outcome reporting. Summary characteristics by approach (eSKA, EEA, or mTCA) are highlighted in Tables 1 and 2. Individual study characteristics are displayed in Tables 5 and 6 (Appendix B).

\section{Gross total resection}

\section{Tuberculum sellae meningioma}

GTR was reported in 10 eSKA (112 patients), 22 EEA (429 patients), and 38 mTCA (1381 patients) studies. Pooled incidence of GTR (Fig. 2; Appendix C) was highest in the mTCA group at $89.56 \%$ (95\% CI 87.04-92.08) followed by eSKA at $85.21 \%$ (95\% CI 73.96-96.46) and EEA at $83.95 \%$ (95\% CI 79.28-88.63). Study heterogeneity was significant within the 
Table 1 Summary study characteristics for tuberculum sellae meningioma papers. WHO: World Health Organisation, mNOS: modified Newcastle Ottawa Score

\begin{tabular}{|c|c|c|c|c|c|c|}
\hline & \multicolumn{2}{|c|}{ Endoscopic endonasal approach } & \multicolumn{2}{|c|}{$\begin{array}{l}\text { Endoscope-assisted supraorbital } \\
\text { keyhole approach }\end{array}$} & \multicolumn{2}{|c|}{ Microscopic transcranial approach } \\
\hline & Amount & Data unavailable & Amount & Data unavailable & Amount & Data unavailable \\
\hline Aggregate number of studies & 26 & - & 11 & - & 42 & - \\
\hline Total number of patients & 540 & - & 128 & - & 1523 & - \\
\hline Median mean age (years) & 54.4 & 4 studies & 57 & 1 study & 53.8 & 8 studies \\
\hline Median male $\%$ & $25 \%$ & 4 studies & $16.7 \%$ & 2 studies & $23.4 \%$ & 5 studies \\
\hline Median number of WHO grade 1 & 20 & 15 studies & 11.5 & 5 studies & 26.5 & 26 studies \\
\hline $\begin{array}{l}\text { Median mean tumour diameter }(\mathrm{cm}) \\
\text { Median mean tumour volume }\left(\mathrm{cm}^{3}\right)\end{array}$ & $\begin{array}{l}2.5 \text { ( } 7 \text { studies }) \\
6.1 \text { (10 studies) }\end{array}$ & 9 studies & $\begin{array}{l}2.9 \text { ( } 2 \text { studies }) \\
12.4 \text { ( } 7 \text { studies })\end{array}$ & 2 studies & $\begin{array}{l}2.5 \text { (17 studies) } \\
8.2 \text { ( } 8 \text { studies })\end{array}$ & 17 studies \\
\hline Median mean follow-up (months) & 27 & 6 studies & 39.8 & 1 study & 39.5 & 5 studies \\
\hline Median mNOS score & 4 & - & 5 & - & 4 & - \\
\hline
\end{tabular}

eSKA $\left(I^{2}=68 \%\right.$, Cochran's $\left.p<0.01\right)$ and mTCA $\left(\mathrm{I}^{2}=60 \%\right.$, Cochran's $p<0.01)$ groups, with Begg's test for publication bias also significant in this mTCA group $(p<0.01)$ (Table 3 ). This impacted funnel plot asymmetry, which was most marked in the mTCA group, without any major change in summary effect using trim and fill across subgroups (Appendix D). Meta-regression suggests male sex was significantly associated with lower GTR incidence in EEA (slope 0.05 (95\% CI - 0.96-0.04)) and mTCA (slope - 0.27 (95\% CI -0.53 to -0.01$)$ ) subgroups (Table 3 ).

\section{Olfactory groove meningioma}

GTR incidence was reported in 8 eSKA (75 patients), 9 mTCA (100 patients), and 28 mTCA (1295 patients) studies. The pooled incidence of GTR (Fig. 3; Appendix C) was highest in the mTCA group with $91.08 \%$ (95\% CI 87.9194.24), followed by eSKA with $84.9 \%$ (95\% CI 50.42-100) and EEA at $82.78 \%$ (95\% CI 72.3-93.26). In terms of study heterogeneity, this was significant within the eSKA $\left(I^{2}=98 \%\right.$, Cochran's $p<0.01)$ and mTCA $\left(I^{2}=81 \%\right.$, Cochran's $p$ $<0.01)$ groups, with Begg's test for publication bias also significant in this mTCA group $(p<0.01)$ (Table 4). These findings are similar to those of the TSM group. Funnel plot asymmetry was most marked in mTCA (reflective of heterogeneity and publication bias) and eSKA (likely reflective of heterogeneity groups). There was no major change in summary effect using trim-and fill-method across subgroups (Appendix D). In the eSKA subgroup, older age was associated with increased GTR on meta-regression (slope 0.05 (95\% CI 0.02-0.08)) (Table 4).

\section{Visual improvement}

\section{Tuberculum sellae meningioma}

Pre-operative visual impairment was reported in 6 eSKA (77 patients), 19 EEA (366 patients), and 36 mTCA (1280

Table 2 Summary study characteristics for olfactory groove meningioma papers. WHO: World Health Organisation, mNOS: modified Newcastle Ottawa Score

\begin{tabular}{|c|c|c|c|c|c|c|}
\hline & \multicolumn{2}{|c|}{ Endoscopic endonasal approach } & \multicolumn{2}{|c|}{$\begin{array}{l}\text { Endoscope-assisted supraorbital } \\
\text { keyhole approach }\end{array}$} & \multicolumn{2}{|c|}{ Microscopic transcranial approach } \\
\hline & Amount & Data unavailable & Amount & Data unavailable & Amount & Data unavailable \\
\hline Aggregate number of studies & 10 & - & 9 & - & 29 & - \\
\hline Total number of patients & 115 & - & 96 & - & 1308 & - \\
\hline Median mean age (years) & 53.1 & 1 studies & 59.2 & 1 studies & 54 & 4 studies \\
\hline Median male $\%$ & $22.5 \%$ & 2 studies & $57.1 \%$ & 2 studies & $32.4 \%$ & 3 studies \\
\hline Median number of WHO grade 1 & 9 & 5 studies & 8.5 & 7 studies & 48 & 13 studies \\
\hline $\begin{array}{l}\text { Median mean tumour diameter }(\mathrm{cm}) \\
\text { Median mean tumour volume }\left(\mathrm{cm}^{3}\right)\end{array}$ & $\begin{array}{l}4 \text { (1 study) } \\
33.3 \text { ( } 5 \text { studies) }\end{array}$ & 4 studies & $\begin{array}{l}\text { NA } \\
24.8 \text { (6 studies) }\end{array}$ & 3 studies & $\begin{array}{l}4.6 \text { (15 studies }) \\
42.5 \text { (4 studies) }\end{array}$ & 10 studies \\
\hline Median mean follow-up (months) & 35.3 & 2 studies & 5 & 1 studies & 54 & 1 studies \\
\hline Median mNOS score & 4.5 & - & 45.1 & - & 4 & - \\
\hline
\end{tabular}



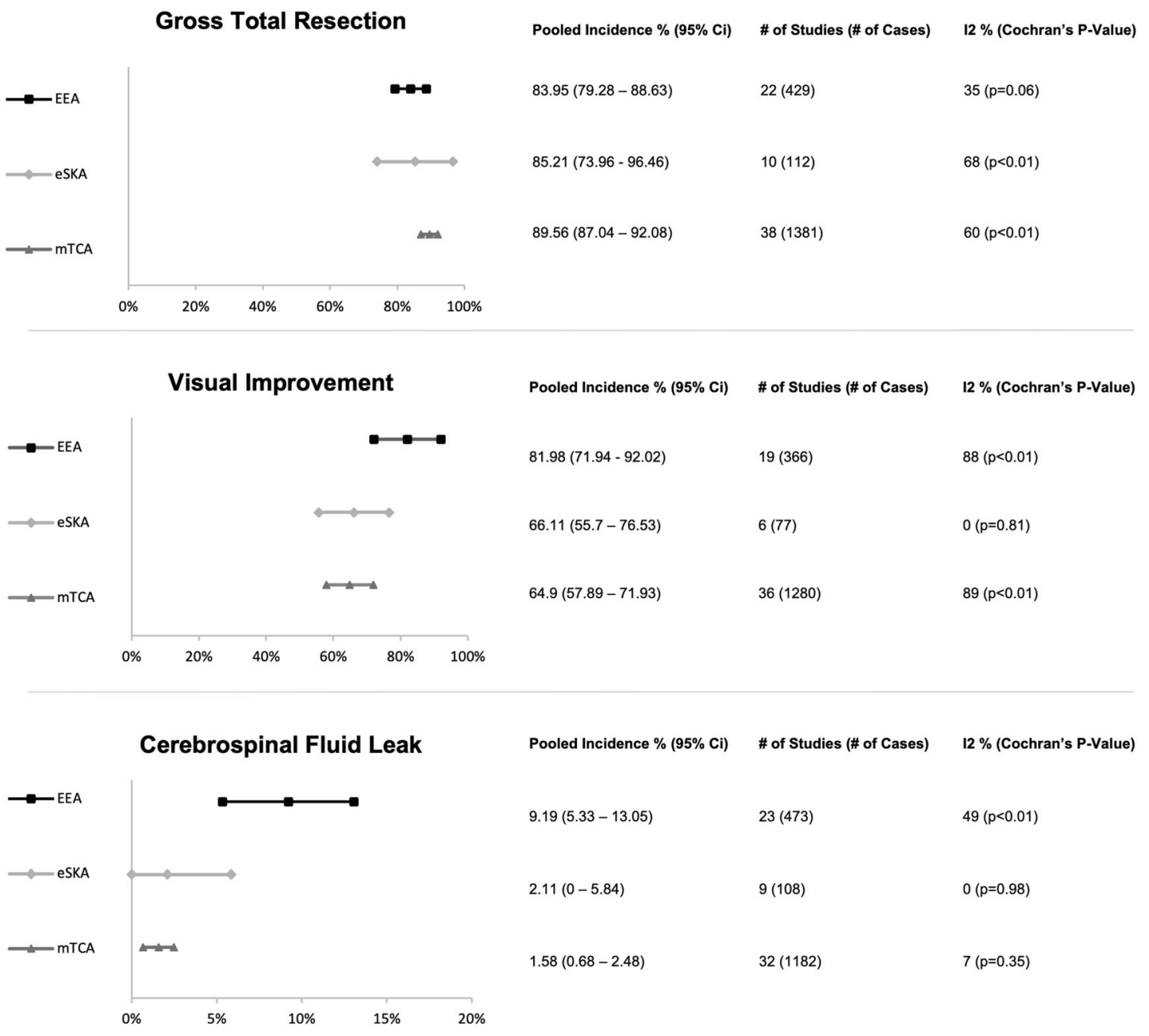

$\begin{array}{lll}\text { Pooled Incidence \% (95\% Ci) } & \text { \# of Studies (\# of Cases) } & \mathbf{1 2} \% \text { (Cochran's P-Value) } \\ 9.19(5.33-13.05) & 23(473) & 49(p<0.01) \\ 2.11(0-5.84) & 9(108) & 0(p=0.98) \\ 1.58(0.68-2.48) & 32(1182) & 7(p=0.35) \\ & & \end{array}$

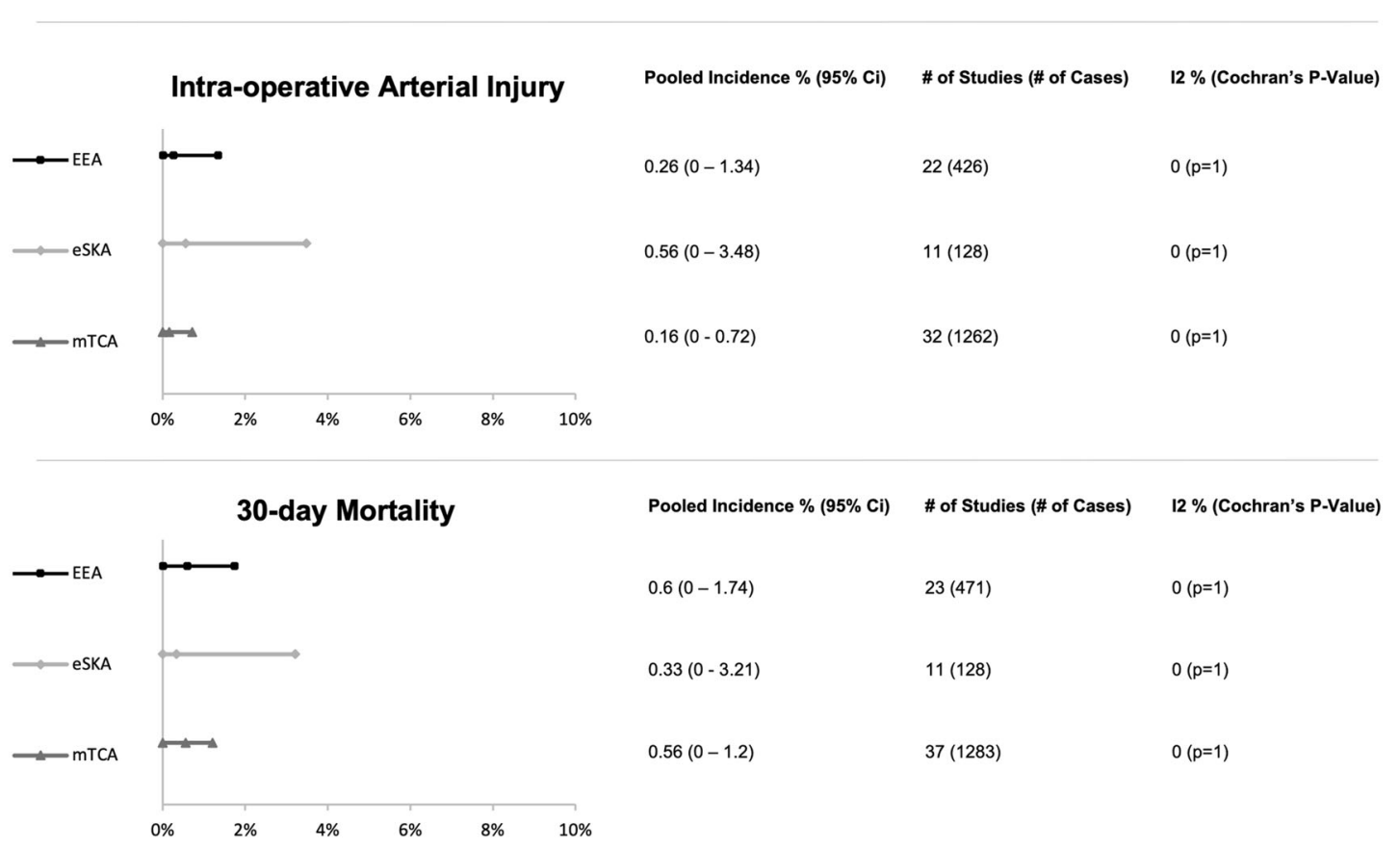

Fig. 2 Graphical display of pooled random effects per outcome metric for Tuberculum Sellae Meningioma. EEA: Expanded endonasal approach, eSKA: Endoscope assisted supra-orbital keyhole approach, mTCA: Microscopic transcranial approach, CI: Confidence Interval 
Table 3 Outcomes of the tuberculum sellae meningioma (TSM) - meta-regression based on age and male percentage. CI - confidence interval, NA not available

\begin{tabular}{|c|c|c|c|c|c|}
\hline Outcomes in TSM & $\begin{array}{l}\text { Begg's test } \\
\text { (p-value) }\end{array}$ & $\begin{array}{l}\text { Meta-regression on } \\
\text { age slope }(95 \% \mathrm{CI})\end{array}$ & $\begin{array}{l}\text { Meta-regression } \\
\text { on age ( } p \text {-value) }\end{array}$ & $\begin{array}{l}\text { Meta-regression on } \\
\text { sex slope }(95 \% \mathrm{CI})\end{array}$ & $\begin{array}{l}\text { Meta-regression } \\
\text { on sex ( } p \text {-value) }\end{array}$ \\
\hline \multicolumn{6}{|l|}{$\begin{array}{l}\text { Gross total resection } \\
\quad \text { (Simpson Grade } 1 \text { Or 2) }\end{array}$} \\
\hline Expanded endonasal approach & 0.32 & $0.003(-0.006-0.01)$ & 0.51 & $-0.5(-0.96-0.04)$ & 0.33 \\
\hline $\begin{array}{l}\text { Endoscope-assisted supraorbital } \\
\text { keyhole approach }\end{array}$ & 0.32 & $0.03(-0.01-0.06)$ & 0.06 & $-0.75(-1.75-0.26)$ & 0.14 \\
\hline Microscopic transcranial approach & $<0.01$ & $0.001(-0.005-0.007)$ & 0.75 & $-0.27(-0.53--0.01)$ & 0.04 \\
\hline \multicolumn{6}{|l|}{ Visual improvement } \\
\hline Expanded endonasal approach & 0.67 & $-0.005(-0.01-0.005)$ & 0.36 & $-0.38(-0.82-0.06)$ & 0.09 \\
\hline $\begin{array}{l}\text { Endoscope-assisted supraorbital } \\
\text { keyhole approach }\end{array}$ & NA & NA & NA & NA & NA \\
\hline Microsopic transcranial approach & 0.35 & $-0.005(-0.02-0.01)$ & 0.57 & $0.11(-0.68-0.91)$ & 0.78 \\
\hline \multicolumn{6}{|l|}{ Cerebrospinal fluid leak } \\
\hline Expanded endonasal approach & 0.03 & $-0.001(-0.008-0.008)$ & 0.95 & $-0.04(-0.47-0.39)$ & 0.86 \\
\hline $\begin{array}{l}\text { Endoscope-assisted supraorbital } \\
\text { keyhole approach }\end{array}$ & 0.21 & $-0.001(-0.01-0.01)$ & 0.83 & $-0.08(-0.47-0.31)$ & 0.7 \\
\hline Microscopic transcranial approach & $<0.01$ & $0.001(-0.003-0.004)$ & 0.75 & $0.07(-0.04-0.18)$ & 0.23 \\
\hline \multicolumn{6}{|l|}{ Intra-operative arterial injury } \\
\hline Expanded endonasal approach & $<0.01$ & $0.001(-0.004$ to -0.004$)$ & 0.88 & $-0.02(-0.21-0.17)$ & 0.84 \\
\hline $\begin{array}{l}\text { Endoscope-assisted supraorbital } \\
\text { keyhole approach }\end{array}$ & 0.01 & $-0.001(-0.008-0.008)$ & 0.95 & $0.01(-0.33-0.35)$ & 0.95 \\
\hline Microsopic transcranial approach & $<0.01$ & $-9.53(-0.002-0.002)$ & 0.91 & $-0.006(-0.07-0.06)$ & 0.87 \\
\hline \multicolumn{6}{|l|}{ 30-day mortality } \\
\hline Expanded endonasal approach & $<0.01$ & $0.002(-0.003-0.006)$ & 0.48 & $0.04(-0.18-0.26)$ & 0.74 \\
\hline $\begin{array}{l}\text { Endoscope-assisted supraorbital } \\
\text { keyhole approach }\end{array}$ & $<0.01$ & $0.001(-0.007-0.009)$ & 0.87 & $-0.02(-0.36-0.3)$ & 0.87 \\
\hline Microsopic transcranial approach & $<0.01$ & $0.001(-0.001-0.002)$ & 0.57 & $-0.001(-0.07-0.07)$ & 0.99 \\
\hline
\end{tabular}

patients) studies. The pooled incidence of visual improvement (Fig. 2; Appendix C) in the EEA group was $81.98 \%$ (95\% CI 71.94-92.02) and was higher than the eSKA at $65.98 \%$ (95\% CI 54.4-77.56) and mTCA at 63.9\% (95\% CI 57.15-70.65). However, study heterogeneity was significant within the EEA $\left(I^{2}=88 \%\right.$, Cochran's $\left.p<0.01\right)$ and mTCA $\left(I^{2}=89 \%\right.$, Cochran's $p<0.01)$ groups. Publication bias was not evident on Begg's testing, with mild funnel plot asymmetry in mTCA and EEA groups likely due to heterogeneity. This is supported by the lack of its major change in summary effect using trimand-fill across subgroups (Appendix D). Meta-regression on age and sex did not reach statistical significance across mTCA, EEA, and eSKA groups (Table 3).

\section{Olfactory groove meningioma}

Pre-operative visual impairment was reported in 2 eSKA (12 patients), 6 EEA (30 patients), and 11 mTCA (236 patients) studies. The pooled incidence of visual improvement (Fig. 3; Appendix C) in descending order were as follows: EEA at $54.56 \%$ (95\% CI 20.4-88.73), eSKA at $52.93 \%$ (95\% CI 0100 ) and mTCA with $45.71 \%$ (95\% CI 24.54-66.88)-a similar pattern to the TSM group. Study heterogeneity was significant across all subgroups: EEA $\left(I^{2}=85 \%\right.$, Cochran's $p<0.01)$, eSKA $\left(I^{2}=93 \%\right.$, Cochran's $\left.p<0.01\right)$, and mTCA $\left(I^{2}=95 \%\right.$, Cochrans $\left.p<0.01\right)$. Publication bias was evident in the EEA cohort (Begg test, $p=0.04$ ), with both this and the above heterogeneity contributing to the marked funnel plot asymmetry (Appendix D). Using the trim and fill method does not display a marked difference in summary effects (Appendix D). Meta-regression on age and sex did not reach statistical significance across subgroups (Table 4).

\section{Cerebrospinal fluid leakage}

\section{Tuberculum sellae meningioma}

Incidence of postoperative CSF leakage was reported in 9 eSKA (108 patients), 23 EEA (473 patients), and 32 mTCA (1182 patients) studies. The pooled incidence of CSF leak (Fig. 2; Appendix C) in the EEA group was 9.19\% (95\% CI 5.33-13.05), which was higher than the incidence observed among the eSKA treated group at $2.11 \%$ (95\% CI 0-5.84) and mTCA treated group at $1.58 \%$ (95\% CI 0.68-2.48). However, 


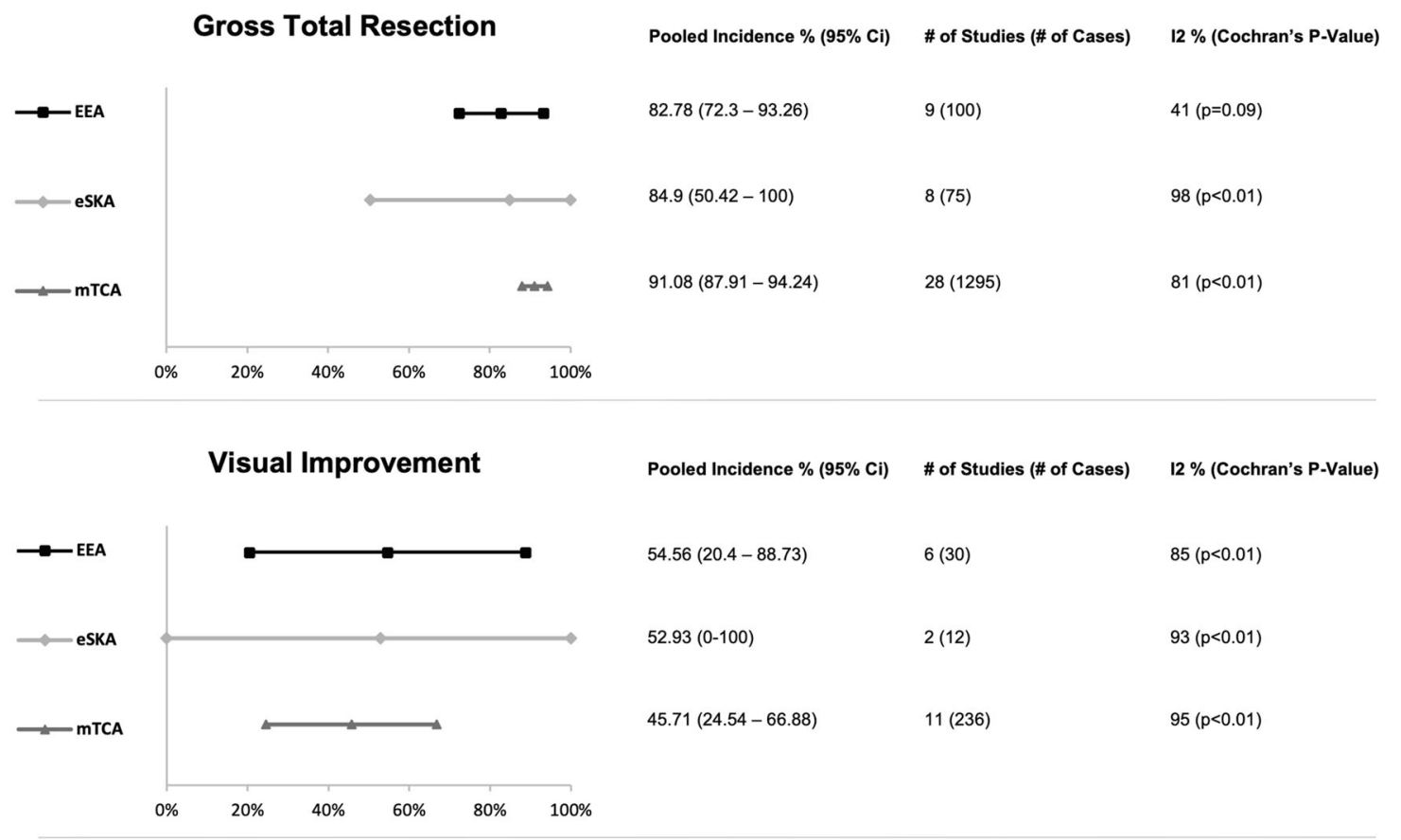

\section{Cerebrospinal Fluid Leak}

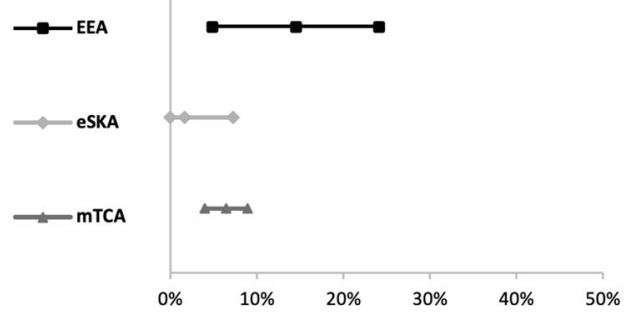

Pooled Incidence \% $(95 \% \mathrm{Ci})$

\# of Studies (\# of Cases)

$12 \%$ (Cochran's P-Value)

$14.46(4.82-24.1)$

9 (109)

$44(p=0.07)$

$1.61(0-7.27)$

7 (58)

$0(p=0.92)$

$6.45(3.95-8.95)$

$26(1132)$

$76(p<0.01)$

\section{Intra-operative Arterial Injury}
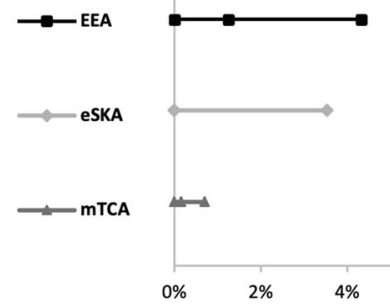

$10(115)$

$0(p=1)$

$0(0-3.52)$

9 (96)

$0(p=1)$

$0.15(0-0.7)$

27 (1142)

$0(p=1)$

30-day Mortality

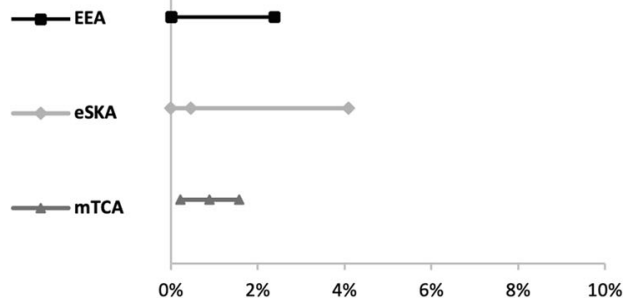

Pooled Incidence \% (95\% Ci) \# of Studies (\# of Cases) $\quad$ 12 \% (Cochran's P-Value)

$0(0-2.38) \quad 23(471) \quad 10(115)$

$0.45(0-4.09) \quad 9(96) \quad 9(96)$

$0.89(0.21-1.57) \quad 10(115) \quad 29(1298)$

Fig. 3 Graphical display of pooled random effects per outcome metric for Olfactory Groove Meningioma. EEA: Expanded endonasal approach, eSKA: Endoscope assisted supra-orbital keyhole approach, mTCA: Microscopic transcranial approach, CI: Confidence Interval 
Table 4 Outcomes of the olfactory groove meningioma (OGM): Meta-regression based on age and male percentage. CI - confidence interval, NA Not available

\begin{tabular}{|c|c|c|c|c|c|}
\hline Outcomes in OGM & Begg's test ( $p$-value) & $\begin{array}{l}\text { Meta-regression on } \\
\text { age slope }(95 \% \mathrm{CI})\end{array}$ & $\begin{array}{l}\text { Meta-regression } \\
\text { on age ( } p \text {-value) }\end{array}$ & $\begin{array}{l}\text { Meta-regression on } \\
\text { sex slope }(95 \% \mathrm{CI})\end{array}$ & $\begin{array}{l}\text { Meta-regression } \\
\text { on sex ( } p \text {-value) }\end{array}$ \\
\hline \multicolumn{6}{|c|}{ Gross total resection (Simpson Grade 1 Or 2) } \\
\hline Expanded endonasal approach & 1 & $-0.01(-0.02-0.01)$ & 0.45 & $-0.3(-1.34-0.74)$ & 0.58 \\
\hline $\begin{array}{l}\text { endoscope-assisted supraorbital } \\
\text { keyhole approach }\end{array}$ & 0.51 & $0.05(0.02-0.08)$ & $<0.01$ & $-0.28(-2.29-1.71)$ & 0.78 \\
\hline Microsopic transcranial approach & 0.01 & $0.01(-0.01-0.01)$ & 0.49 & $-0.01(-0.29-0.28)$ & 0.96 \\
\hline \multicolumn{6}{|l|}{ Visual improvement } \\
\hline Expanded endonasal approach & 0.04 & $-5.07(-0.04-0.04)$ & 0.99 & $0.3(-3.3-3.9)$ & 0.87 \\
\hline $\begin{array}{l}\text { Endoscope-assisted supraorbital } \\
\text { keyhole approach }\end{array}$ & NA & NA & NA & NA & NA \\
\hline Microsopic transcranial approach & 0.48 & $0.03(-0.06-0.12)$ & 0.55 & $-0.47(-3.25-2.3)$ & 0.74 \\
\hline \multicolumn{6}{|l|}{ Cerebrospinal fluid leak } \\
\hline Expanded endonasal approach & 0.64 & $-0.002(-0.02-0.01)$ & 0.85 & $0.79(0.2-1.38)$ & 0.01 \\
\hline $\begin{array}{l}\text { Endoscope-assisted supraorbital } \\
\text { keyhole approach }\end{array}$ & NA & NA & NA & NA & NA \\
\hline Microsopic transcranial approach & 0.01 & $-0.002(-0.009-0.005)$ & 0.51 & $0.001(-0.23-0.23)$ & 0.99 \\
\hline \multicolumn{6}{|l|}{ Intra-operative arterial injury } \\
\hline Expanded endonasal approach & 0.02 & $0.001(-0.001-0.01)$ & 0.86 & $0.08(-0.29-0.44)$ & 0.68 \\
\hline $\begin{array}{l}\text { Endoscope-assisted supraorbital } \\
\text { keyhole approach }\end{array}$ & NA & $0(-0.008-0.008)$ & 1 & $0(-0.24-0.24)$ & 1 \\
\hline Microsopic transcranial approach & 0.01 & $-4.56(-0.002-0.001)$ & 0.95 & $-0.01(-0.08-0.05)$ & 0.68 \\
\hline \multicolumn{6}{|l|}{ 30-day mortality } \\
\hline Expanded endonasal approach & 0.01 & $0(-0.01-0.01)$ & 1 & $0(-0.35-0.35)$ & 1 \\
\hline $\begin{array}{l}\text { Endoscope-assisted supraorbital } \\
\text { keyhole approach }\end{array}$ & 0.01 & $-0.001(-0.008-0.007)$ & 0.97 & $-0.06(-0.33-0.21)$ & 0.66 \\
\hline Microsopic transcranial approach & 0.01 & $-0.001(-0.003-0.001)$ & 0.07 & $-0.09(-0.16-0.02)$ & 0.01 \\
\hline
\end{tabular}

study heterogeneity $\left(I^{2}=49 \%\right.$, Cochran's $\left.p<0.01\right)$ and publication bias (Begg's $\mathrm{p}=0.03$ ) were significant in the EEA group. Publication bias was also evident in the mTCA group (Begg's $p \leq 0.01$ ). The asymmetry of mTCA and EEA funnel plots is explained by the above (Appendix D), but no major change in summary effect using the trim-and-fill method is appreciable in these groups. Meta-regression on age and sex did not reach statistical significance across any group (Table 3).

\section{Olfactory groove meningioma}

Incidence of post-op CSF leakage was reported in 7 eSKA (58 patients), 9 EEA (109 patients), and 26 mTCA (1132 patients) studies. Pooled incidence of CSF leak (Fig. 3; Appendix C) in the EEA group was $14.46 \%$ (95\% CI 4.82-24.1), 6.45\% in the mTCA group (95\% CI 3.95-8.95), and $1.61 \%$ (95\% CI 0$7.27)$ in the eSKA group. Study heterogeneity was evident in the mTCA group ( $\mathrm{I}^{2}=76 \%$, Cochran's $\left.p<0.01\right)$, whilst publication bias was suggested in the mTCA (Begg's $p \leq$ 0.01 ) and eSKA (Begg's $p=0.03$ ). Indeed, mTCA and eSKA funnel plots reflect this in their asymmetry (Appendix
D). Meta-regression suggested male sex was associated with increased CSF leak in the EEA approach (slope 0.79 (95\% CI 0.2-1.38)) (Table 4).

\section{Intraoperative arterial injury}

\section{Tuberculum sellae meningioma}

Incidence of intraoperative arterial injury was reported in 11 eSKA (128 patients), 22 EEA (426 patients), and 32 mTCA (1262 patients) studies. Pooled incidence (Fig. 2; Appendix C) in descending order were as follows: eSKA $-0.56 \%(95 \% \mathrm{CI}$ $0-3.48)$, EEA - 0.26\% (95\% CI 0-1.34), and mTCA - $0.16 \%$ (95\% CI 0-0.72). Across all 3 groups, study heterogeneity was not apparent; however, publication bias using Begg's test reached statistical significance in eSKA $(p=0.01)$, EEA $(p<$ $0.01)$, and mTCA $(p<0.01)$ groups - explaining funnel plot asymmetry across groups. Trim and fill adjustment, however, made almost no difference in overall summary effects (Appendix D). Meta-regression did not reveal significant associations for age and sex across all treatment groups (Table 3). 


\section{Olfactory groove meningioma}

Incidence of intraoperative arterial injury was reported in 9 eSKA (96 patients), 10 EEA (115 patients), and 27 mTCA (1142 patients) studies. Pooled incidence (Fig. 3; Appendix C) was highest in the EEA group at $1.25 \%$ (95\% CI 0-4.32), followed by the mTCA at $0.15 \%(95 \%$ CI $0-0.7)$ and eSKA with $0 \%$ (95\% CI 0-3.52). Indeed, these results do not align with the TSM group. Across all 3 groups, study heterogeneity was not apparent; however, publication bias using Begg's test reached statistical significance in EEA $(p=0.02)$ and mTCA $(p<0.01)$ groups, mapping to funnel plot asymmetry in EEA and mTCA groups. However, trim and fill adjustment made only minor differences to the estimated summary effect (Appendix D). Again, meta-regression did not show a significant effect of age and sex on arterial injury (Table 4).

\section{0-day mortality}

\section{Tuberculum sellae meningioma}

Incidence of mortality was reported in 11 eSKA (128 patients), 23 EEA (471 patients), and 37 mTCA (1283 patients) studies. Pooled incidence of 30-day mortality (Fig. 2; Appendix C) was $0.6 \%$ (95\% CI 0-1.74) in the EEA group, followed by $0.56 \%(95 \%$ CI $0-1.2)$ in mTCA and $0.33 \%$ (95\% CI 0-3.21) in eSKA in descending order. Across all 3 groups, study heterogeneity was not apparent; however, publication bias using Begg's test reached statistical significance in all three groups $(p<0.01)$. Resultantly, the mTCA and eSKA funnel plots are asymmetrical but are not appreciably impacted in terms of summary effect by the implementation of trim and fill (Appendix D). Meta-regression did not show a significant effect of age and sex on mortality across subgroups (Table 3).

\section{Olfactory groove meningioma}

Incidence of mortality was reported in 9 eSKA (96 patients), 10 EEA (115 patients), and 23 mTCA (471 patients) studies. Unlike, the TSM population, pooled incidence of 30-day mortality (Fig. 3; Appendix C) was greatest in the mTCA group at $0.89 \%$ (95\% CI 0.21-1.57), followed by the eSKA at $0.45 \%$ (95\% CI 0-4.09) and EEA with 0\% (95\% CI 0-2.38). Across all 3 groups, study heterogeneity was not apparent; however, publication bias using Begg's test reached statistical significance in all groups $(p<0.1)$, mapping to funnel plot asymmetry in EEA and mTCA groups (Appendix D). Trim and fill implementation did not result in any major adjustment to the estimated summary effect. Male sex appeared to be associated with higher 30-day mortality in the mTCA (slope - $0.09(95 \%$ CI - 0.016-0.02)) (Table 4).

\section{Sensitivity analysis with low risk of bias studies}

The pooled incidence of surgical outcomes of a subgroup of low-risk studies (defined as mNOS score greater than or equal to 4) is presented in Appendix E. This analysis, when compared with the total group analysis, yielded overall similar results for GTR, mortality, and intraoperative arterial injury. CSF leak incidence after EEA was apparently lower (in both OGM and TSM), and visual improvements after EEA (in the TSM group) were more marked in the lower risk of bias studies.

\section{Discussion}

\section{Principle findings}

In the context of heterogeneous study populations and outcome reporting, the endoscope-assisted supraorbital "keyhole" approach appeared to be associated with similar effectiveness (GTR, visual improvement) and safety (CSF leak, 30-day mortality) compared with the mTCA and EEA alternatives based on our findings. Case selection and an understanding of relative indications are important in selecting the most appropriate approach for anterior skull base meningioma resection.

As previously found, the EEA was associated with the highest rates of visual improvement across OGM and TSM groups. However, this advantage of EEA may be offset when considering the safety profile of the three approaches, with the EEA having the highest incidence of post-op CSF leak (statistically significant in the TSM sub-group). In contrast, the mTCA had a slightly higher incidence of GTR than eSKA and EEA (eSKA > EEA) across TSM and OGM groups. Interestingly, the eSKA displays intermediate results in terms of efficacy (GTR and visual improvement) and complications (CSF leak). Results for intra-operative arterial injury and 30day mortality incidences are similar and overlapping across the 3 approaches. Indeed, the eSKA, as a relatively new technique, is less well explored. When compared with the mTCA, the eSKA — as a minimally invasive technique - offers a smaller craniotomy scar, less brain exposure, and less brain/nerve retraction [105]. Thus, theoretically, it shares similar limitations to the minimally invasive EEA [92] — potentially making total resection of larger tumours or tumours with significant local invasion difficult $[24,92,105]$. However, when performed with the benefit of neuronavigation, neuroendoscopy (12/13 of eSKA studies in our meta-analysis), and appropriate surgical training, the eSKA has been used to resect relatively large tumours of the anterior skull base [4, 41, 67, 105].

All 3 approaches likely have their own role in the management of anterior skull base meningiomas, with their varying safety and efficacy profiles as evidenced above. Case selection will be paramount in establishing a role for each technique/ combination of techniques $[4,92,105]$. Indeed, case selection 
of eSKA is currently considerably variable, owing to its novelty and ongoing refinement $[70,92]$. The selection of the preferred approach for each case must be taken in the context: (a) patientrelated factors (demographic, presentation, preferences), (b) tumour-related factors (size, consistency, extension, locationsuch as relation to optic foramen or cribriform plate), and (c) surgeon experience, surgeon preference, and surgical goals (such as GTR or STR, visual or olfactory preservation) [2, 77, 92, 105, 118]. Ottenhausen et al. presents a concise decision-making algorithm (based on tumour anatomy and resulting functional deficits), which incorporates the specific characteristics of eSKA, EEA, and mTCA approaches [92]. In this algorithm, the eSKA is suitable for TSMs with lateral extension up to the internal carotid arteries (ICA) and anterior clinoid processes (ACP), or lateral extension beyond the lamina papyracea (LP). Additionally, the eSKA is suggested for OGMs with (1) preserved olfaction and (2) disrupted olfaction without cribriform plate invasion but with significant anterior (up to the frontal sinus) or lateral extension. In contrast, the EEA is proposed for TSM without significant lateral extension (ICA/ACP/LP as above) and OGMs without significant lateral extension (where olfaction is disrupted). Finally, an mTCA or a combined EEA + eSKA approach is suggested for OGMs and TSMs with a significant anterior or lateral extension (unless there is no cribriform plate invasion, in which case, eSKA alone may be possible) [92]. Of note, other algorithms cite $>5 \mathrm{~mm}$ sellar extension and optic canal involvement as factors favouring EEA in TSM [60]. During EEA for TSM, decompression of the optic canal from below avoids excessive vascular manipulation, can be achieved before or after tumour resection, and is well suited to tumours with extension into the inferomedial aspect of the optic canal [2, 69]. Decompression of the involved optic canal is described in mTCA approaches with early decompression (before tumour resection) favoured $[20,80,90]$. In eSKA, studies describe both early and late bilateral canal decompression with optimum timing being less clear [16, 67]. More generally, within the literature, consensus for the ideal surgical approach in various contexts is not clear $[41,60,67,74,92,99]$. Indeed, in light of the COVID-19 pandemic - which elucidated to the risk endonasal surgery may pose (exposing theatre staff to high viral loads and potentially serious infection)- this case selection process is likely to be a dynamic field in the near future [71, 100, 119].

\section{Findings in the context of other syntheses}

Previous meta-analyses have compared the EEA and mTCA (not eSKA) with varying results.

In terms of GTR, Muskens et al. (co-author) previously found higher GTR incidence with mTCA in OGM at $88.5 \%$ (CI 85.9-90.7\%) versus EEA 70.9\% (CI 60.3-79.9\%) [84]in line with our findings. This corroborates with other metaanalyses. Ruggeri et al. explored OGM and TSM, finding a higher GTR rate $(p<0.01)$ in mTCA $(88.13 \%)$ than EEA
$(78,42 \%)$ [110]. Similarly, Komotor et al. highlighted a $92.8 \%$ GTR rate in mTCA, compared with $63.2 \%$ in EEA (0.001) in the context of TSM and OGM [59], whilst Shetty et al. explored GTR in OGM, finding a significantly $(p<0.01)$ higher rate in mTCA $(90.9 \%)$ than in EEA (70.2\%) [115].

Regarding visual outcomes, a recent comparative metaanalysis by $\mathrm{Lu}$ et al. suggests improved visual outcome in OGM resection using the EEA (vs. mTCA) (OR, 0.318; $p=$ 0.04 ) but not statistically significant in TSM [73]. This is slightly different from our updated findings and previous findings of Muskens et al. [84], in which the visual outcome advantage of EEA was most prominent in the TSM group. In other analyses, an early (2013) study by Clark et al. displayed higher $(p<0.01)$ visual improvement incidence in TSM with EEA (50-100\% in included studies) compared with mTCA studies (25-78\%) [24]. Shetty et al. explored OGM alone and found $80.7 \%$ visual improvement in the EEA studies group versus $12.83 \%$ in the mTCA group $(p<0.01)$ [115]. Ruggeri et al. replicated these findings when taking OGM and TSM as a collective group, with EEA displaying an $80.1 \%$ incidence visual improvement, significantly $(p<0.01)$ higher than mTCA $(62.2 \%)$ [110].

In terms of CSF leak rate, Muskens et al. highlighted this as a disadvantage to the EEA in both TSM (EEA: 19.3\% $(95 \%$ CI 14.1-25.8\%), mTCA 5.8\% (95\% CI 4.3- 7.8\%)) and OGM (EEA: $25.1 \%$ (95\% CI 17.5-34.8\%), mTCA $10.5 \%$ (95\% CI 8.2-13.4\%)) [84]. This finding is echoed throughout relevant secondary literature, with $\mathrm{Lu}$ et al. highlighting a higher CSF leak incidence in EEA (vs mTCA) in TSM (OR 3.854; $p=0.013$ ) and Shetty et al. showcasing a $25.7 \% \mathrm{CSF}$ leak occurrence in EEA versus $6.3 \%$ in mTCA $(p<0.01)[73$, 115]. In taking TSM and OGM, together, Komotor et al. demonstrated a higher CSF leak incidence of $21.3 \%$ in EEA, compared with $4.3 \%$ in mTCA $(p<0.01)$, whilst Ruggeri et al. illustrated $18.84 \%$ CSF leak occurrence in EEA versus $5.95 \%$ in mTCA $(p<0.01)[110,115]$.

Finally, when considering 30-day mortality, significant associations have been difficult to establish both in our study and the literature. Ruggeri et al. found mortality rates of $2.3 \%$ in $\mathrm{mTCA}$ and $1.03 \%$ in EEA in TSM and OGM, but this did not reach statistical significance $(p=0.154)$ [110]. Similarly, differences in mortality explored by Muskens et al. were inconclusive in TSM (EEA: $5.2 \%$ (95\% CI 3.4-10.8\%), mTCA $2.7 \%(95 \%$ CI 1.8-4\%)) and OGM (EEA: $4.3 \%$ (95\% CI 1.5$11.6 \%)$, mTCA $3.9 \%$ (95\% CI 2.7-5.8\%)) [84]. A similar situation is found with intra-op arterial injury incidence with most syntheses not highlighting significant differences, echoed by our updated analysis [24, 59, 110, 115].

\section{Limitations and strengths}

The principal limitations of this study are the likely prevalent publication bias and heterogeneity of the primary literature synthesized, more specifically heterogeneity in the reporting 
of baseline characteristics and outcomes. This is reflected in the $I^{2}$ and Cochran $Q$ tests highlight in Figs. 2 and 3, corroborating with respective funnel charts (Appendix B). Development of core data set, through a multi-stakeholder consensus process for example, would be useful for future pooled analysis in the field. Secondly, it is likely the study populations examined are considerably variable owing to the surgical decision-making process that informs the choice of approach. Larger, more extensive tumours may be more likely to undergo traditional open approaches (of which there are many variants) in order to achieve acceptable tumour resection [84]. This is reflected in Tables 1 and 2 where larger (diameter and/or volume) tumours are included in the mTCA group compared with the EEA group. Unfortunately, we were not able to perform meta-regression based on tumour size or grade owing to heterogeneous data reporting, potentially adding to confounding factors $[18,46]$. Additionally, the overwhelming majority of studies included were case series, and thus, our interpretation of our results should be tempered to reflect this. Finally, owing to the novelty of the approach, there is a relative paucity in the amount of included eSKA studies. Although overall, the results of the main analysis are similar to that of the sensitivity analysis subgroup, the number of low risk of bias studies analyzed is also limited. Future studies in the field must improve on methodological design, with an emphasis on comparative studies, in order to facilitate more robust data synthesis.

\section{Conclusions}

In the context of diverse study populations and heterogeneous case selection criteria, the endoscope-assisted supraorbital keyhole approach appeared not to be associated with increased adverse outcomes when compared with expanded endonasal and traditional transcranial approaches and offered comparable effectiveness. Case selection is paramount in establishing a role for the supraorbital keyhole approach in anterior skull base tumours. Development of standardized research databases and well-designed comparative studies that control for selection and confounding biases are needed to further delineate these selection criteria.

Author contributions All authors contributed to the study conception and design. Material preparation, data collection, and analysis were performed by DZK, ISM, RAM, AHZ, and HJM. The first draft of the manuscript was written by DZK, and all authors commented on previous versions of the manuscript. All authors read and approved the final manuscript.

Funding No specific funding was received for this research. HJM is funded by the Wellcome/EPSRC Centre for Interventional and Surgical Sciences (WEISS) and the National Institute of Health Research University College London Biomedical Research Centre. AEH is supported by the Cambridge Biomedical Research Centre.

\section{Compliance with ethical standards}

Conflict of interest The authors declare that they have no conflict of interest.

Ethical approval Ethical approval was unnecessary due to the nature of the study (study-level meta-analysis).

Informed consent Not applicable due to the nature of the study (studylevel meta-analysis).

Open Access This article is licensed under a Creative Commons Attribution 4.0 International License, which permits use, sharing, adaptation, distribution and reproduction in any medium or format, as long as you give appropriate credit to the original author(s) and the source, provide a link to the Creative Commons licence, and indicate if changes were made. The images or other third party material in this article are included in the article's Creative Commons licence, unless indicated otherwise in a credit line to the material. If material is not included in the article's Creative Commons licence and your intended use is not permitted by statutory regulation or exceeds the permitted use, you will need to obtain permission directly from the copyright holder. To view a copy of this licence, visit http://creativecommons.org/licenses/by/4.0/.

\section{References}

1. Ali MZE-MS, Al-Azzazi A (2010) Tuberculum sellae meningiomas: surgical results and outcome in 30 cases. Egyptian J Neurol: 549-554

2. Attia M, Kandasamy J, Jakimovski D, Bedrosian J, Alimi M, Lee DLY, Anand VK, Schwartz TH (2012) The importance and timing of optic canal exploration and decompression during endoscopic endonasal resection of tuberculum sella and planum sphenoidale meningiomas. Operative Neurosurgery 71:ons58ons67

3. Bander ED, Singh H, Ogilvie CB, Cusic RC, Pisapia DJ, Tsiouris AJ, Anand VK, Schwartz TH (2017) Endoscopic endonasal versus transcranial approach to tuberculum sellae and planum sphenoidale meningiomas in a similar cohort of patients. J Neurosurg 128:40-48

4. Banu MA, Mehta A, Ottenhausen M, Fraser JF, Patel KS, Szentirmai O, Anand VK, Tsiouris AJ, Schwartz TH (2016) Endoscope-assisted endonasal versus supraorbital keyhole resection of olfactory groove meningiomas: comparison and combination of 2 minimally invasive approaches. J Neurosurg 124:605620

5. Barzaghi LR, Spina A, Gagliardi F, Boari N, Mortini P (2017) Transfrontal-sinus-subcranial approach to olfactory groove meningiomas: surgical results and clinical and functional outcome in a consecutive series of 21 patients. World Neurosurg 101: 315-324

6. Bassiouni H, Asgari S, Stolke D (2006) Tuberculum sellae meningiomas: functional outcome in a consecutive series treated microsurgically. Surg Neurol 66:37-45. https://doi.org/10.1016/ j.surneu.2005.11.059

7. Bassiouni H, Asgari S, Stolke D (2007) Olfactory groove meningiomas: functional outcome in a series treated microsurgically. Acta Neurochir 149:109-121. https://doi.org/10.1007/s00701006-1075-Z

8. Begg CB, Mazumdar M (1994) Operating characteristics of a rank correlation test for publication bias. Biometrics:1088-1101 
9. Bernat A-L, Priola SM, Elsawy A, Farrash F, Pasarikovski CR, Almeida JP, Lenck S, De Almeida J, Vescan A, Monteiro E (2018) Recurrence of anterior skull base meningiomas after endoscopic endonasal resection: 10 years' experience in a series of 52 endoscopic and transcranial cases. World Neurosurg 120:e107e113

10. Bitter AD, Stavrinou LC, Ntoulias G, Petridis AK, Dukagjin M, Scholz M, Hassler W (2013) The role of the pterional approach in the surgical treatment of olfactory groove meningiomas: a 20-year experience. J Neurol Surg Part B-Skull Base 74:97-102. https:// doi.org/10.1055/s-0033-1333618

11. Bohman L-E, Stein SC, Newman JG, Palmer JN, Adappa ND, Khan A, Sitterley TT, Chang D, Lee JYK (2012) Endoscopic versus open resection of tuberculum sellae meningiomas: a decision analysis. ORL 74:255-263

12. Bohman L-E, Stein SC, Newman JG, Palmer JN, Adappa ND, Khan A, Sitterley TT, Chang D, Lee JYK (2012) Endoscopic versus open resection of tuberculum sellae meningiomas: a decision analysis. Orl J Oto-Rhino-Laryngology Head Neck Surg 74: 255-263. https://doi.org/10.1159/000343794

13. Bowers CA, Altay T, Couldwell WT (2011) Surgical decisionmaking strategies in tuberculum sellae meningioma resection. Neurosurg Focus 30. https://doi.org/10.3171/2011.2.Focus1115

14. Bowers CA, Altay T, Couldwell WT (2011) Surgical decisionmaking strategies in tuberculum sellae meningioma resection. Neurosurg Focus 30:E1

15. Brodbelt AR, Barclay ME, Greenberg D, Williams M, Jenkinson MD, Karabatsou K (2019) The outcome of patients with surgically treated meningioma in England: 1999-2013. A cancer registry data analysis. Br J Neurosurg 33:641-647

16. Cai M, Hou B, Luo L, Zhang B, Guo Y (2019) Trans-eyebrow supraorbital keyhole approach to tuberculum sellae meningiomas: a series of 30 cases with long-term visual outcomes and recurrence rates. J Neuro-Oncol 142:545-555

17. Catapano G, de Notaris M, Di Maria D, Fernandez LA, Di Nuzzo G, Seneca V, Iorio G, Dallan I (2016) The use of a threedimensional endoscope for different skull base tumors: results of a preliminary extended endonasal surgical series. Acta Neurochir 158:1605-1616

18. Cavenee WK, Louis DN, Ohgaki H, Wiestler OD (2007) WHO classification of tumours of the central nervous system, vol 1 WHO Regional Office Europe

19. Ceylan S, Anik I, Koc K, Cabuk B (2015) Extended endoscopic transsphenoidal approach infrachiasmatic corridor. Neurosurg Rev 38:137-147. https://doi.org/10.1007/s10143-014-0576-0

20. Chen L-H, Chen L, Liu L-X (2011) Microsurgical management of tuberculum sellae meningiomas by the frontolateral approach: surgical technique and visual outcome. Clin Neurol Neurosurg 113: 39-47. https://doi.org/10.1016/j.clineuro.2010.08.019

21. Chokyu I, Goto T, Ishibashi K, Nagata T, Ohata K (2011) Bilateral subfrontal approach for tuberculum sellae meningiomas in long-term postoperative visual outcome Clinical article. J Neurosurg 115:802-810. https://doi.org/10.3171/2011.5. Jns101812

22. Chowdhury FH, Haque MR, Goel AH, Kawsar KA (2012) Endoscopic endonasal extended transsphenoidal removal of tuberculum sellae meningioma (TSM): an experience of six cases. Br J Neurosurg 26:692-699. https://doi.org/10.3109/02688697. 2012.673648

23. Ciurea AV, Iencean SM, Rizea RE, Brehar FM (2012) Olfactory groove meningiomas: a retrospective study on 59 surgical cases. Neurosurg Rev 35:195-202. https://doi.org/10.1007/s10143-0110353-2

24. Clark AJ, Jahangiri A, Garcia RM, George JR, Sughrue ME, McDermott MW, El-Sayed IH, Aghi MK (2013) Endoscopic surgery for tuberculum sellae meningiomas: a systematic review and meta-analysis. Neurosurg Rev 36:349-359

25. Colli BO, Carlotti Junior CG, Assirati Junior JA, Marques dos Santos MB, Neder L, dos Santos AC, Batagini NC (2007) Olfactory groove meningiomas - surgical technique and followup review. Arq Neuropsiquiatr 65:795-799. doi:https://doi.org/10. 1590/s0004-282x2007000500012

26. Curey S, Derrey S, Hannequin P, Hannequin D, Freger P, Muraine M, Castel H, Proust F (2012) Validation of the superior interhemispheric approach for tuberculum sellae meningioma Clinical article. J Neurosurg 117:1013-1021. https://doi.org/10.3171/2012.9. Jns 12167

27. de Aguiar PHP, Tahara A, Almeida AN, Simm R, da Silva AN, Maldaun MVC, Panagopoulos AT, Zicarelli CA, Silva PG (2009) Olfactory groove meningiomas: approaches and complications. J Clin Neurosci 16:1168-1173

28. de Almeida JR, Carvalho F, Guimaraes Filho FV, Kiehl T-R, Koutourousiou M, Su S, Vescan AD, Witterick IJ, Zadeh G, Wang EW, Fernandez-Miranda JC, Gardner PA, Gentili F, Snyderman CH (2015) Comparison of endoscopic endonasal and bifrontal craniotomy approaches for olfactory groove meningiomas: A matched pair analysis of outcomes and frontal lobe changes on MRI. J Clin Neurosci 22:1733-1741. https://doi.org/ 10.1016/j.jocn.2015.03.056

29. de Divitiis E, Esposito F, Cappabianca P, Cavallo LM, de Divitiis O (2008) Tuberculum sellae meningiomas: High route or low route? A series of 51 consecutive cases. Neurosurgery 62:556562. https://doi.org/10.1227/01.neu.0000317303.93460.24

30. de Divitiis E, Esposito F, Cappabianca P, Cavallo LM, de Divitiis O, Esposito I (2008) Endoscopic transnasal resection of anterior cranial fossa meningiomas. Neurosurg Focus 25. https://doi.org/ 10.3171/foc.2008.25.12.E8

31. Della Puppa A, d'Avella E, Rossetto M, Volpin F, Rustemi O, Gioffre G, Lombardi G, Rolma G, Scienza R (2015) Open transcranial resection of small $(<35 \mathrm{~mm})$ meningiomas of the anterior midline skull base in current microsurgical practice. World Neurosurg 84. https://doi.org/10.1016/j.wneu.2015.04.055

32. DeMonte F, McDermott MW, Al-Mefty O (2011) Al-Mefty's meningiomas. Thieme

33. DerSimonian R, Laird N (1986) Meta-analysis in clinical trials. Control Clin Trials 7:177-188

34. Duval S, Tweedie R (2000) Trim and fill: a simple funnel plotbased method of testing and adjusting for publication bias in metaanalysis. Biometrics 56:455-463

35. Dzhindzhikhadze RS, Dreval ON, Lazarev VA, Polyakov AV, Kambiev RL, Salyamova EI (2020) Transpalpebral approach for microsurgical removal of tuberculum sellae meningiomas. Asian $\mathrm{J}$ Neurosurg 15:98

36. Egger M, Davey-Smith G, Altman D (2008) Systematic reviews in health care: meta-analysis in context. John Wiley \& Sons

37. Elshazly K, Kshettry VR, Farrell CJ, Nyquist G, Rosen M, Evans JJ (2017) Clinical outcome after endoscopic endonasal resection of tuberculum sella meningiomas. Oper Neurosurg 14:494-502

38. Engelhardt J, Namaki H, Mollier O, Monteil P, Penchet G, Cuny E, Loiseau H (2018) Contralateral transcranial approach to tuberculum sellae meningiomas: long-term visual outcomes and recurrence rates. World Neurosurg 116:e1066-e1074

39. Eroglu U, Shah K, Bozkurt M, Kahilogullari G, Yakar F, Dogan I, Ozgural O, Attar A, Unlu A, Caglar S (2019) Supraorbital keyhole approach: lessons learned from 106 operative cases. World Neurosurg 124:e667-e674

40. Farooq G, Rehman L, Bokhari I, Rizvi SRH (2018) Modern microsurgical resection of olfactory groove meningiomas by classical bicoronal subfrontal approach without orbital osteotomies. Asian J Neurosurg 13:258 
41. Fatemi N, Dusick JR, de Paiva Neto MA, Malkasian D, Kelly DF (2009) Endonasal versus supraorbital keyhole removal of craniopharyngiomas and tuberculum sellae meningiomas. Operative. Neurosurgery 64:ons269-ons287

42. Fountas KN, Hadjigeorgiou GF, Kapsalaki EZ, Paschalis T, Rizea R, Ciurea AV (2018) Surgical and functional outcome of olfactory groove meningiomas: lessons from the past experience and strategy development. Clin Neurol Neurosurg 171:46-52

43. Ganna A, Dehdashti AR, Karabatsou K, Gentili F (2009) Frontobasal interhemispheric approach for tuberculum sellae meningiomas; long-term visual outcome. Br J Neurosurg 23:422-430. https://doi.org/10.1080/02688690902968836

44. Goel A, Bhaganagare A, Shah A, Kaswa A, Rai S, Dharurkar P, Gore S (2018) Olfactory groove meningiomas: An analysis based on surgical experience with 129 cases. Neurol India 66:1081

45. Goel A, Muzumdar D (2005) Surgical strategy for tuberculum sellae meningiomas. Neurosurg Q 15:25-32. https://doi.org/10. 1097/01.wnq.0000152404.94129.45

46. Gousias K, Schramm J, Simon M (2016) The Simpson grading revisited: aggressive surgery and its place in modern meningioma management. J Neurosurg 125:551-560

47. Guduk M, Yener U, Sun HI, Hacihanefioglu M, Ozduman K, Pamir MN (2017) Pterional and unifrontal approaches for the microsurgical resection of olfactory groove meningiomas: experience with 61 consecutive patients. Turk Neurosurg 27:707-715

48. Guo S, Gerganov V, Giordano M, Samii A, Samii M (2020) Elderly patients with frontobasal and suprasellar meningiomas: safety and efficacy of tumor removal via frontolateral approach. World Neurosurg 135:e452-e458

49. Hayashi Y, Kita D, Fukui I, Sasagawa Y, Oishi M, Tachibana O, Ueda F, Nakada M (2017) Preoperative evaluation of the interface between tuberculum sellae meningioma and the optic nerves on fast imaging with steady-state acquisition for extended endoscopic endonasal transsphenoidal surgery. World Neurosurg 103:153160

50. Hayhurst C, Sughrue ME, Gore PA, Bonney PA, Burks JD, Teo C (2016) Results with expanded endonasal resection of skull base meningiomas technical nuances and approach selection based on an early experience. Turk Neurosurg 26:662-670

51. Higgins JPT, Green S (2011) Cochrane handbook for systematic reviews of interventions, vol 4. John Wiley \& Sons

52. Higgins JPT, Thompson SG (2002) Quantifying heterogeneity in a meta-analysis. Stat Med 21:1539-1558

53. Hozo SP, Djulbegovic B, Hozo I (2005) Estimating the mean and variance from the median, range, and the size of a sample. BMC Med Res Methodol 5:13

54. Igressa A, Pechlivanis I, Weber F, Mahvash M, Ayyad A, Boutarbouch M, Charalampaki P (2015) Endoscope-assisted keyhole surgery via an eyebrow incision for removal of large meningiomas of the anterior and middle cranial fossa. Clin Neurol Neurosurg 129:27-33

55. Jang W-Y, Jung S, Jung T-Y, Moon K-S, Kim I-Y (2012) The contralateral subfrontal approach can simplify surgery and provide favorable visual outcome in tuberculum sellae meningiomas. Neurosurg Rev 35:601-607. https://doi.org/10.1007/s10143012-0397-y

56. Jang W-Y, Jung S, Jung T-Y, Moon K-S, Kim I-Y (2013) Preservation of olfaction in surgery of olfactory groove meningiomas. Clin Neurol Neurosurg 115:1288-1292. https://doi.org/10. 1016/j.clineuro.2012.12.004

57. Karsy M, Raheja A, Eli I, Guan J, Couldwell WT (2017) Clinical outcomes with transcranial resection of the tuberculum sellae meningioma. World Neurosurg 108:748-755

58. Khan OH, Anand VK, Schwartz TH (2014) Endoscopic endonasal resection of skull base meningiomas: the significance of a "cortical cuff" and brain edema compared with careful case selection and surgical experience in predicting morbidity and extent of resection. Neurosurg Focus 37. https://doi.org/10.3171/ 2014.7.Focus 14321

59. Komotar RJ, Starke RM, Raper DMS, Anand VK, Schwartz TH (2012) Endoscopic endonasal versus open transcranial resection of anterior midline skull base meningiomas. World Neurosurg 77: 713-724

60. Kong D-S, Hong C-K, Hong SD, Nam D-H, Lee J-I, Seol HJ, Oh J, Kim DG, Kim YH (2018) Selection of endoscopic or transcranial surgery for tuberculum sellae meningiomas according to specific anatomical features: a retrospective multicenter analysis (KOSEN-002). J Neurosurg 130:838-847

61. Koutourousiou M, Fernandez-Miranda JC, Stefko ST, Wang EW, Snyderman CH, Gardner PA (2014) Endoscopic endonasal surgery for suprasellar meningiomas: experience with 75 patients Clinical article. J Neurosurg 120:1326-1339. https://doi.org/10. 3171/2014.2.Jns 13767

62. Koutourousiou M, Fernandez-Miranda JC, Wang EW, Snyderman CH, Gardner PA (2014) Endoscopic endonasal surgery for olfactory groove meningiomas: outcomes and limitations in 50 patients. Neurosurg Focus 37. https://doi.org/10.3171/2014. 7.Focus 14330

63. Kuga D, Toda M, Yoshida K (2018) Treatment strategy for tuberculum sellae meningiomas based on a preoperative radiological assessment. World Neurosurg 120:e1279-e1288

64. Landeiro JA, Goncalves MB, Guimaraes RD, Klescoski J, Amorim Correa JL, Lapenta MA, Maia O (2010) Tuberculum sellae meningiomas: surgical considerations. Arq Neuropsiquiatr 68:424 429. https://doi.org/10.1590/s0004-282x2010000300019

65. Leveque S, Derrey S, Martinaud O, Gerardin E, Langlois O, Freger P, Hannequin D, Castel H, Proust F (2011) Superior interhemispheric approach for midline meningioma from the anterior cranial base. Neurochirurgie 57:105-113. https://doi.org/10.1016/ j.neuchi.2011.08.001

66. Li X, Liu M, Liu Y, Zhu S (2007) Surgical management of tuberculum sellae meningiomas. J Clin Neurosci 14:1150-1154. https://doi.org/10.1016/j.jocn.2006.09.003

67. Linsler S, Fischer G, Skliarenko V, Stadie A, Oertel J (2017) Endoscopic assisted supraorbital keyhole approach or endoscopic endonasal approach in cases of tuberculum sellae meningioma: which surgical route should be favored? World Neurosurg 104: 601-611

68. Liu H-C, Qiu E, Zhang J-L, Kang J, Li Y, Li Y, Jiang L-B, Fu J-D (2015) Surgical indications of exploring optic canal and visual prognostic factors in neurosurgical treatment of tuberculum sellae meningiomas. Chin Med J 128:2307-2311. https://doi.org/10. 4103/0366-6999.163391

69. Liu JK, Christiano LD, Patel SK, Tubbs RS, Eloy JA (2011) Surgical nuances for removal of tuberculum sellae meningiomas with optic canal involvement using the endoscopic endonasal extended transsphenoidal transplanum transtuberculum approach. Neurosurg Focus 30:E2

70. Liu JK, Silva NA, Sevak IA, Eloy JA (2018) Transbasal versus endoscopic endonasal versus combined approaches for olfactory groove meningiomas: importance of approach selection. Neurosurg Focus 44:E8

71. Liu Y, Yan L-M, Wan L, Xiang T-X, Le A, Liu J-M, Peiris M, Poon LLM, Zhang W (2020) Viral dynamics in mild and severe cases of COVID-19. Lancet Infect Dis

72. Louis DN, Perry A, Reifenberger G, Von Deimling A, FigarellaBranger D, Cavenee WK, Ohgaki H, Wiestler OD, Kleihues P, Ellison DW (2016) The 2016 World Health Organization classification of tumors of the central nervous system: a summary. Acta Neuropathol 131:803-820

73. Lu VM, Goyal A, Rovin RA (2018) Olfactory groove and tuberculum sellae meningioma resection by endoscopic endonasal 
approach versus transcranial approach: a systematic review and meta-analysis of comparative studies. Clin Neurol Neurosurg

74. Magill ST, Morshed RA, Lucas C-HG, Aghi MK, Theodosopoulos PV, Berger MS, de Divitiis O, Solari D, Cappabianca P, Cavallo LM (2018) Tuberculum sellae meningiomas: grading scale to assess surgical outcomes using the transcranial versus transsphenoidal approach. Neurosurg Focus 44:E9

75. Mahmoud M, Nader R, Al-Mefty O (2010) Optic canal involvement in tuberculum sellae meningiomas: influence on approach, recurrence, and visual recovery. Neurosurgery 67:108-118. https://doi.org/10.1227/01.Neu.0000383153.75695.24

76. Margalit N, Shahar T, Barkay G, Gonen L, Nossek E, Rozovski U, Kesler A (2013) Tuberculum sellae meningiomas: surgical technique, visual outcome, and prognostic factors in 51 cases. J Neurol Surg Part B-Skull Base 74:247-257. https://doi.org/10.1055/s0033-1342920

77. Mariniello G, de Divitiis O, Bonavolonta G, Maiuri F (2013) Surgical unroofing of the optic canal and visual outcome in basal meningiomas. Acta Neurochir 155:77-84. https://doi.org/10. 1007/s00701-012-1485-z

78. Marx S, Clemens S, Schroeder HWS (2017) The value of endoscope assistance during transcranial surgery for tuberculum sellae meningiomas. J Neurosurg 128:32-39

79. Mathiesen T, Kihlstrom L (2006) Visual outcome of tuberculum sellae meningiomas after extradural optic nerve decompression. Neurosurgery 59:570-575. https://doi.org/10.1227/01.Neu. 0000228683.79123.F9

80. Mathiesen T, Kihlström L (2006) Visual outcome of tuberculum sellae meningiomas after extradural optic nerve decompression. Neurosurgery 59:570-576

81. Moher D, Liberati A, Tetzlaff J, Altman DG (2009) Preferred reporting items for systematic reviews and meta-analyses: the PRISMA statement. Ann Intern Med 151:264-269

82. Mortazavi MM, da Silva HB, Ferreira M Jr, Barber JK, Pridgeon JS, Sekhar LN (2016) Planum sphenoidale and tuberculum sellae meningiomas: operative nuances of a modern surgical technique with outcome and proposal of a new classification system. World Neurosurg 86:270-286

83. Mukherjee S, Thakur B, Corns R, Connor S, Bhangoo R, Ashkan $\mathrm{K}$, Gullan R (2015) Resection of olfactory groove meningioma - a review of complications and prognostic factors. Br J Neurosurg 29:685-692. https://doi.org/10.3109/02688697.2015.1054348

84. Muskens IS, Briceno V, Ouwehand TL, Castlen JP, Gormley WB, Aglio LS, Najafabadi AHZ, van Furth WR, Smith TR, Mekary RA (2018) The endoscopic endonasal approach is not superior to the microscopic transcranial approach for anterior skull base meningiomas - a meta-analysis. Acta Neurochir 160:59-75

85. Nakamura M, Roser F, Struck M, Vorkapic P, Samii M (2006) Tuberculum sellae meningiomas: clinical outcome considering different surgical approaches. Neurosurgery 59:1019-1028. https://doi.org/10.1227/01.Neu.0000245600.92322.06

86. Nakamura M, Struck M, Roser F, Vorkapic P, Samii M (2007) Olfactory groove meningiomas: clinical outcome and recurrence rates after tumor removal through the frontolateral and bifrontal approach. Neurosurgery 60:844-852

87. Nakamura M, Struck M, Roser F, Vorkapic P, Samii M (2008) Olfactory groove meningiomas: clinical outcome and recurrence rates after tumor removal through the frontolateral and bifrontal approach. Neurosurgery 62:1224-1231. https://doi.org/10.1227/ 01.Neu.0000255453.20602.80

88. Nanda A, Ambekar S, Javalkar V, Sharma M (2013) Technical nuances in the management of tuberculum sellae and diaphragma sellae meningiomas. Neurosurg Focus 35. https://doi.org/10.3171/ 2013.10.Focus 13350

89. Nanda A, Maiti TK, Bir SC, Konar SK, Guthikonda B (2016) Olfactory groove meningiomas: comparison of extent of frontal lobe changes after lateral and bifrontal approaches. World Neurosurg 94:211-221. https://doi.org/10.1016/j.wneu.2016.06. 101

90. Nozaki K, K-i K, Takagi Y, Mineharu Y, Takahashi JA, Hashimoto N (2008) Effect of early optic canal unroofing on the outcome of visual functions in surgery for meningiomas of the tuberculum sellae and planum sphenoidale. Neurosurgery 62: 839-846

91. Ogawa Y, Tominaga T (2012) Extended transsphenoidal approach for tuberculum sellae meningioma - what are the optimum and critical indications? Acta Neurochir 154:621-626. https://doi. org/10.1007/s00701-011-1266-0

92. Ottenhausen M, Rumalla K, Alalade AF, Nair P, La Corte E, Younus I, Forbes JA, Nsir AB, Banu MA, Tsiouris AJ (2018) Decision-making algorithm for minimally invasive approaches to anterior skull base meningiomas. Neurosurg Focus 44:E7

93. Padhye V, Naidoo Y, Alexander H, Floreani S, Robinson S, Santoreneos S, Wickremesekera A, Brophy B, Harding M, Vrodos N, Wormald P-J (2012) Endoscopic endonasal resection of anterior skull base meningiomas. Otolaryngol Head Neck Surg 147:575-582. https://doi.org/10.1177/0194599812446565

94. Paiva-Neto MAd, Tella-Jr OId (2010) Supra-orbital keyhole removal of anterior fossa and parasellar meningiomas. Arq Neuropsiquiatr 68:418-423

95. Palani A, Panigrahi MK, Purohit AK (2012) Tuberculum sellae meningiomas: a series of 41 cases; surgical and ophthalmological outcomes with proposal of a new prognostic scoring system. J Neurosci Rural Pract 3:286-293. https://doi.org/10.4103/09763147.102608

96. Pallini R, Fernandez E, Lauretti L, Doglietto F, D'Alessandris QG, Montano N, Capo G, Meglio M, Maira G (2015) Olfactory groove meningioma: report of 99 cases surgically treated at the Catholic University School of Medicine, Rome. World Neurosurg 83:219. https://doi.org/10.1016/j.wneu.2014.11.001

97. Pamir MN, Ozduman K, Belirgen M, Kilic T, Ozek MM (2005) Outcome determinants of pterional surgery for tuberculum sellae meningiomas. Acta Neurochir 147:1121-1130. https://doi.org/10. 1007/s00701-005-0625-0

98. Park C-K, Jung H-W, Yang S-Y, Seol HJ, Paek SH, Kim DG (2006) Surgically treated tuberculum sellae and diaphragm sellae meningiomas: the importance of short-term visual outcome. Neurosurgery 59:238-243. https://doi.org/10.1227/01.Neu. 0000223341.08402.C5

99. Patel K, Kolias AG, Santarius T, Mannion RJ, Kirollos RW (2018) Results of transcranial resection of olfactory groove meningiomas in relation to imaging-based case selection criteria for the endoscopic approach. Oper Neurosurg 16:539-548

100. Patel ZM, Fernandez-Miranda J, Hwang PH, Nayak JV, Dodd R, Sajjadi H, Jackler RK (2020) Precautions for endoscopic transnasal skull base surgery during the COVID-19 pandemic. Neurosurgery. https://doi.org/10.1093/neuros/nyaa125

101. Pepper J-P, Hecht SL, Gebarski SS, Lin EM, Sullivan SE, Marentette LJ (2011) Olfactory groove meningioma: discussion of clinical presentation and surgical outcomes following excision via the subcranial approach. Laryngoscope 121:2282-2289. https://doi.org/10.1002/lary.22174

102. Perneczky A, Reisch R (2009) Keyhole approaches in neurosurgery: volume 1: concept and surgical technique, vol 1 Springer Science \& Business Media

103. Refaat MI, Eissa EM, Ali MH (2015) Surgical management of midline anterior skull base meningiomas: experience of 30 cases. Turk Neurosurg 25:432-437. https://doi.org/10.5137/1019-5149. Jtn.11632-14.2

104. Reisch R, Marcus HJ, Hugelshofer M, Koechlin NO, Stadie A, Kockro RA (2014) Patients' cosmetic satisfaction, pain, and 
functional outcomes after supraorbital craniotomy through an eyebrow incision. J Neurosurg 121:730-734

105. Reisch R, Perneczky A (2005) Ten-year experience with the supraorbital subfrontal approach through an eyebrow skin incision. Operative. Neurosurgery 57:ONS-242

106. Reisch R, Perneczky A, Filippi R (2003) Surgical technique of the supraorbital key-hole craniotomy. Surg Neurol 59:223-227

107. Reisch R, Stadie A, Kockro RA, Hopf N (2013) The keyhole concept in neurosurgery. World Neurosurg 79:S17-e19

108. Romani R, Laakso A, Kangasniemi M, Niemelä M, Hernesniemi J (2012) Lateral supraorbital approach applied to tuberculum sellae meningiomas: experience with 52 consecutive patients. Neurosurgery 70:1504-1519

109. Romani R, Lehecka M, Gaal E, Toninelli S, Çelik Ö, Niemelä M, Porras M, Jääskeläinen J, Hernesniemi J (2009) Lateral supraorbital approach applied to olfactory groove meningiomas: experience with 66 consecutive patients. Neurosurgery 65:39-53

110. Ruggeri AG, Cappelletti M, Fazzolari B, Marotta N, Delfini R (2016) Frontobasal midline meningiomas: is it right to shed doubt on the transcranial approaches? Updates and review of the literature. World Neurosurg 88:374-382

111. Salek MAA, Faisal MH, Manik MAH, Choudhury A-U-M, Chowdhury RU, Islam MA (2020) Endoscopic endonasal transsphenoidal approach for resection of tuberculum sella and planum sphenoidale meningiomas: a snapshot of our institutional experience. Asian J Neurosurg 15:22

112. Schick U, Hassler W (2005) Surgical management of tuberculum sellae meningiomas: involvement of the optic canal and visual outcome. J Neurol Neurosurg Psychiatry 76:977-983. https:// doi.org/10.1136/jnnp.2004.039974

113. Schroeder HWS, Hickmann A-K, Baldauf J (2011) Endoscopeassisted microsurgical resection of skull base meningiomas. Neurosurg Rev 34:441-455

114. Seol HJ, Park H-Y, Nam D-H, Kong D-S, Lee J-I, Kim JH, Park K (2013) Clinical outcomes of tuberculum sellae meningiomas focusing on reversibility of postoperative visual function. Acta Neurochir 155:25-31. https://doi.org/10.1007/s00701-012-15516

115. Shetty SR, Ruiz-Treviño AS, Omay SB, Almeida JP, Liang B, Chen Y-N, Singh H, Schwartz TH (2017) Limitations of the endonasal endoscopic approach in treating olfactory groove meningiomas. A systematic review. Acta Neurochir 159:1875-1885

116. Simpson D (1957) The recurrence of intracranial meningiomas after surgical treatment. J Neurol Neurosurg Psychiatry 20:22

117. Slavik E, Radulovic D, Tasic G (2007) Olfactory groove meningiomas. Acta Chir Iugosl 54:59-62

118. Smith KA, Leever JD, Chamoun RB (2015) Predicting consistency of meningioma by magnetic resonance imaging. J Neurol Surg B Skull Base 76:225-229. https://doi.org/10.1055/s-00341543965

119. Society of British Neurological Surgeons (SBNS) (2020) Transmission Of Covid-19 During neurosurgical procedures. https:/www.sbns.org.uk/index.php/download_file/view/1658/ 416/. Accessed 01/06/2020 2020

120. Song SW, Kim YH, Kim JW, Park C-K, Kim JE, Kim DG, Koh Y-C, H-w J (2018) Outcomes after transcranial and endoscopic endonasal approach for tuberculum meningiomas - a retrospective comparison. World Neurosurg 109:e434-e445

121. Spektor S, Valarezo J, Fliss DM, Gil Z, Cohen J, Goldman J, Umansky F (2005) Olfactory groove meningiomas from neurosurgical and ear, nose, and throat perspectives: approaches, techniques, and outcomes. Neurosurgery 57:268-279. https:// doi.org/10.1227/01.Neu.0000176409.70668.Eb

122. Telera S, Carapella CM, Caroli F, Crispo F, Cristalli G, Raus L, Sperduti I, Pompili A (2012) Supraorbital keyhole approach for removal of midline anterior cranial fossa meningiomas: a series of 20 consecutive cases. Neurosurg Rev 35:67-83

123. Tuna H, Bozkurt M, Ayten M, Erdogan A, Deda H (2005) Olfactory groove meningiomas. J Clin Neurosci 12:664-668. https://doi.org/10.1016/j.jocn.2005.05.002

124. Voznyak O, Lytvynenko A, Maydannyk O, Ilyuk R, Zinkevych Y, Hryniv N (2020) Tuberculum sellae meningioma surgery: visual outcomes and surgical aspects of contralateral approach. Neurosurg Rev:1-7

125. Wang Q, Lu X-J, Ji W-Y, Yan Z-C, Xu J, Ding Y-S, Zhang J (2010) Visual outcome after extended endoscopic endonasal transsphenoidal surgery for tuberculum sellae meningiomas. World Neurosurg 73:694-700. https://doi.org/10.1016/j.wneu. 2010.04.007

126. Wells GA, Tugwell P, O'Connell D, Welch V, Peterson J, Shea B, Losos M (2015) The Newcastle-Ottawa Scale (NOS) for assessing the quality of nonrandomized studies in meta-analyses. http:// www.ohri.ca/programs/clinical_epidemiology/oxford.asp. Accessed 01/06/20 2020

127. Wilk A, Zielinski G, Witek P, Koziarski A (2016) Outcome assessment after surgical treatment of tuberculum sellae meningiomas - a preliminary report. Turk Neurosurg 26:824 832. https://doi.org/10.5137/1019-5149.Jtn.14160-15.1

128. Xiao J, Wang W, Wang X, Mao Z, Qi H, Cheng H, Yu Y (2018) Supraorbital keyhole approach to the sella and anterior skull base via a forehead wrinkle incision. World Neurosurg 109:e343-e351

129. Xu M, Xu J, Huang X, Chen D, Chen M, Zhong P (2019) Small extended bifrontal approach for midline anterior skull base meningiomas: our experience with 54 consecutive patients. World Neurosurg 125:e35-e43

130. Zhou H, Wu Z, Wang L, Zhang J (2016) Microsurgical treatment of tuberculum sellae meningiomas with visual impairments: a chinese experience of 56 cases. Turk Neurosurg 26:48-53. https:// doi.org/10.5137/1019-5149.Jtn.11476-14.1

131. Zoli M, Guaraldi F, Pasquini E, Frank G, Mazzatenta D (2018) The endoscopic endonasal management of anterior skull base meningiomas. J Neurol Surg Part B: Skull Base 79:S300-S310

\section{Comments}

The authors have updated their previous meta-analysis on anterior fossa meningiomas, recognizing that the transcranial group comprises a huge variety of traditional approaches and newer minimally invasive techniques. It is important to compare modern microsurgical approaches against long established skull base methods, so it is no longer just about "above or below."

Caroline Hayhurst

Wales, UK

Publisher's note Springer Nature remains neutral with regard to jurisdictional claims in published maps and institutional affiliations. 